\title{
RISK BASED INTERNAL AUDITING DAN IMPLEMENTASINYA PADA PT IBF
}

\author{
Choirul Anwar \\ President University, Jababeka Education Park, Jln. Ki Hajar Dewantara, \\ Kota Jababeka, Bekasi, 17550 \\ anwar_choirul@yahoo.com
}

\begin{abstract}
Risks deal with uncertainties. The bigger the uncertainties faced by firms, the larger opportunity and impact of the risks in future. Whether firms succeed in managing risks it depends a lot on the effectivity of internal control. PT Indonesia Buffon Film (PT IBF) is one of many firms trying to optimalize its Internal Audit Department.The main problem in this company is managing the company to survive with accumulated losses over 90\% of share capital in the period of 2007 to 2008. This research aims to describe the relationship between internal control and purpose of Internal Audit Department of PT IBF. The main focus is the management crisis happening due to weak leadership within the company. This in turn weakens internal control. Management is suggested to prioritize risks that contribute to the main risk, especially internal factors that can be controlled by management. PT IBF has deployed an implementation of the Australian/New Zealand Standard in Risk Management (AZ/NZS 4360) that helps the main purpose of the Risk Based Internal Auditing. Overall, PT IBF has done well to recognize that there are possible risks in their business operations. However, there are also gaps that must be analyzed and followed up further by management.
\end{abstract}

Keywords: internal control, risk based internal audit, PT IBF

\begin{abstract}
ABSTRAK
Risiko berurusan dengan ketidakpastian. Semakin besar ketidakpastian yang dihadapi oleh perusahaan, akan semakin besar kesempatan dan dampak risiko yang ada di masa mendatang. Efektivitas pengendalian internal sangat mempengaruhi keberhasilan perusahaan dalam mengelola risiko. PT Indonesia Buffon Film (PT IBF) adalah salah satu dari banyak perusahaan mencoba untuk mengoptimalkan Bagian Audit Internal. Masalah utama dalam perusahaan ini adalah mengelola perusahaan untuk bertahan dengan akumulasi kerugian lebih dari 90\% dari modal saham pada periode 2007 hingga 2008. Penelitian ini bertujuan untuk menggambarkan hubungan antara pengendalian internal dan tujuan Bagian Audit Internal PT IBF. Fokus utama adalah krisis manajemen yang sedang terjadi akibat lemahnya leadership dalam perusahaan sehingga berakibat pada lemahnya internal control. Dalam tahap ini, manajemen diarahkan untuk memberikan prioritas utama yang berkontribusi terhadap risiko utama, terutama faktor internal yang dapat dikendalikan manajemen. PT IBF telah menerapakan pelaksanaan The Australian/New Zealand Standard in Risk Management (AZ/NZS 4360) yang membantu tujuan utama dari Risk Based Internal Auditing. Secara keseluruhan, PT IBF telah berhasil dengan baik mengenali kemungkinan risiko yang ada di dalam operasi usahanya. Namun, masih ada juga celah-celah kelemahan yang harus dianalisis dan ditindaklanjuti oleh manajemen.
\end{abstract}

Kata kunci: pengendalian internal, audit internal berbasis risiko, PT IBF 


\section{PENDAHULUAN}

Sesuai dengan eksternal auditor, internal auditor report atau opini internal auditor sangat diperlukan untuk mengevaluasi kinerja internal control perusahaan. Namun, sayangnya banyak persepsi yang timbul sekarang bahwa internal audit hanya berhubungan atau ditujukan untuk mengawasi kegiatan keuangan atau financial control saja. Manajemen perusahaan juga banyak menyimpulkan bahwa kontrol merupakan tanggung jawab dari akuntan perusahaan dan eksternal auditor semata sehingga menyebabkan para manajer non financial dan accounting merasa tidak memiliki atas pengendalian internal tersebut. Padahal para manajer non financial dan accounting tersebut mampu mengetahui secara langsung risiko-risiko yang ada dan mengarah kepada tanggung jawabnya sebagai komponen pimpinan perusahaan.

Penelitian ini menggambarkan pengkajian studi kasus tentang praktik penerapan manajemen risiko di PT Indonesia Buffon Film (IBF) dan kaitannya dengan proses audit berbasis risiko (riskbased audit). Manajemen perusahaan sebenarnya sudah mengerti akan permasalahan, namun belum bisa untuk mengorganisasikan dengan baik permasalahan dan pemecahan persoalan yang ada. Dengan adanya penugasan pengkajian Enterprise Risk Management dan kaitannya dengan Risk-Based Audit ini sangatlah membantu penulis dalam proses belajar dan sekaligus implementasi di lapangan secara langsung.

Permasalahan utama yang ada di perusahaan ini adalah bagaimana caranya perusahaan bisa survive di masa yang akan datang, dengan akumulasi kerugian yang sudah melebihi $90 \%$ dari setoran modal perusahaan (share capital) di tahun 2007-2008. Permasalahan ini dalam penerapan Enterprise Risk Management, penulis golongkan dalam Risk Identification yang utama. Dengan kata lain, bukan berarti tidak ada lagi risiko-risiko lain yang bisa diidentifikasikan. Namun, berangkat dari identifikasi risiko yang utama inilah penulis diarahkan management perusahaan untuk mengkaji risiko-risiko yang berkontribusi terhadap risiko utama.

Tujuan dari penelitian ini adalah untuk membantu pembaca memahami fungsi dan peran internal control dalam suatu perusahaan, dalam hal ini di PT IBF serta memahami peran internal audit dalam menentukan ukuran keakuratan internal control dalam melaksanakan tugasnya me-manage perusahaan untuk mencapai tujuan yang sudah ditentukan sebelumnya.

Manfaat umum dari penelitian ini adalah hasil penelitian ini dapat dipergunakan oleh pembaca sebagai bahan informasi maupun pertimbangan dalam mengatasi permasalahan yang timbul untuk pengambilan keputusan, baik masa sekarang maupun akan datang. Sedangkan manfaat khusus tulisan ini adalah untuk memberikan kesempatan kepada penulis untuk mengetahui masalah-masalah yang sebenarnya dihadapi oleh PT IBF dalam menentukan pos-pos yang krusial dan penentuan risiko yang harus dihadapi oleh internal control sehingga risiko tersebut dapat di-manage dengan baik, berkat bantuan dari hasil pemeriksaan internal auditor atas efektifitas internal control tersebut.

Dengan demikian, internal audit bertugas membantu internal control perusahaan yang dilakukan oleh Board of Director, manajemen, dan personel lainnya yang didesain untuk memberikan keyakinan memadai atas pencapaian objektif dalam beberapa kategori sebagai berikut (1) Kehandalan dan kecermatan dari laporan keuangan; (2) Sesuai dengan hukum dan aturan (regulasi) yang berlaku; (3) Efisien, efektif, dan ekonomisnya operasi organisasi atau perusahaan.

Untuk memenuhi berbagai pengawasan yang berhubungan dengan tujuan (objective) perusahaan, COSO mendidentifikasi komponent internal control yang terdiri dari (1) Control environment, yang menentukan irama organisasi, yang berhubungan dengan kontrol terhadap orang (people). Hal ini merupakan fondasi untuk semua komponen internal control yang menyajikan 
kedisiplinan dan struktur dalam internal control; (2) Risk assessment adalah identifikasi dari organisasi dan analisis relevansi dari risiko untuk mencapai objektifnya serta menentukan bagaimana risiko-risiko yang ada seharusnya dikelola secara baik; (3) Control activities adalah prosedur dan kebijakan yang membantu untuk meyakinkan manajemen dalam mengarahkan perusahaan dalam pencapaian tujuannya; (4) Information and communication yang merupakan identifikasi, pencapaian, dan pertukaran informasi dalam ruang lingkup dan waktu yang memperbolehkan orang (people) untuk menjalankan tanggung jawabnya; (5) Monitoring adalah proses yang menilai kualitas internal control performance dalam kurun waktu tertentu.

Faktor-faktor yang berkontribusi terhadap perkembangan internal audit adalah (1) Ukuran dari bisnis menjadi semakin kompleks dan menyebar secara meluas yang mengharuskan manajemen menggantungkan pada berbagai laporan dan analisis untuk mengontrol operasi perusahaan secara efisien; (2) Pengecekan dan review yang tidak dapat dipisahkan (inherent) dalam sistem yang baik dari internal audit serta melindungi terhadap kelemahan manusia dan mengurangi kemungkinan kesalahan atau ketidaknormalan yang akan terjadi; (3) Suatu yang tidak lazim bagi auditor untuk mengaudit perusahaan yang dibatasi ekonomi tanpa adanya bantuan dari internal audit suatu klien.

Lebih lanjut perlu diuraikan pengertian dan peran internal audit dalam organisasi atau perusahaan. Sesuai definisi yang dikeluarkan oleh International Auditing Auditors (IIA), Internal Auditing adalah sebuah aktivitas independent, keyakinan yang objektif, dan aktivitas konsultasi yang didesain untuk menambah dan memperbaiki operasi sebuah organisasi.

Yang dimaksud dengan risiko dipandang dari hasil keluaran adalah sebuah hasil atau keluaran yang tidak dapat diprediksikan dengan pasti, yang tidak disukai karena akan menjadi kontra produktif. Sedangkan risiko dipandang dari segi proses adalah faktor-faktor yang dapat mempengaruhi pencapaian tujuan sehingga terjadinya konsekuensi yang tidak diinginkan. Risiko dalam sudut pandang proses operasional perusahaan seringkali disebut dengan faktor risiko. Pada intinya, kedua sudut pandang yaitu dari segi hasil keluaran dan proses, faktor risiko saling melengkapi satu sama lain. Perbedaan di antara keduanya hanya sekedar perspektif dan posisi pengguna maupun penganalisis.

Secara umum, komponen risiko adalah sebagai berikut. Pertama, risiko inherent yaitu risiko yang secara intrinsik lahir karena terjadinya suatu aktivitas dan melekat pada aktivitas itu sendiri. Sebagai contoh adalah suatu perusahaan meluncurkan produk baru. Perusahaan ini akan menghadapi risiko bahwa produk barunya tersebut tidak akan diterima di pasar. Contoh lainnya adalah jika perusahaan menjual produknya dengan cara kredit, maka hal ini mempunyai risiko kegagalan kredit prlanggan. Kedua, risiko terkendali yaitu bagian dari risiko inherent yang dapat dikendalikan melalui aplikasi atau aktivitas pengendalian tertentu. Risiko ini merujuk kepada tindakan perusahaan untuk mengurangi cakupan risiko inherent melalui suatu aplikasi kendali risiko. Sebagai contoh, untuk mengurangi cakupan risiko peluncuran produk baru, sebuah perusahaan dapat melakukan riset pasar sebelum launching produk barunya tersebut, atau melakukan pilot project di pasar tertentu sebelum peluncuran produk secara nasional. Untuk mengurangi cakupan kegagalan kredit pelanggan, sebuah perusahaan dapat mengenakan kriteria yang lebih ketat seperti jaminan bank atau pembayaran sebagian di muka sebelum mengirimkan barang kepada pelanggan. Dalam kehidupan sehari-hari, kita tidak dapat menghentikan hujan, tetapi dapat membawa payung atau jas hujan agar tidak kebasahan. Ketiga, risiko residual yaitu tingkat atau besaran risiko yang tetap melekat pada suatu aktivitas tertentu walaupun aplikasi pengendalian sudah diterapkan. Sebagai contoh, bagaimanapun baiknya riset pasar dilakukan, kegagalan dari peluncuran produk baru di pasaran tertentu selalu mungkin terjadi. Mengenakan kriteria yang lebih ketat bagi pelanggan perusahaan masih belum menghilangkan kemungkinan kegagalan kredit. Hal yang sama dengan kehidupan kita sehari-hari, menggunakan payung selama hujan tidak akan menjamin 100\% bahwa kita tidak akan kebasahan.

Risiko adalah kondisi yang melibatkan keterpaparan terhadap pencapaian tujuan entitas perusahaan, baik yang bersifat secara langsung maupun tidak langsung, yang merupakan hasil dari 
sebuah kombinasi antara kemungkinan terjadinya sebuah peristiwa dan besaran dari konsekuensinya. Bagi entitas komersial atau bisnis, istilah risiko sering digunakan bergantian dengan istilah risiko bisnis atau risiko korporat. Cakupan risiko bisnis sangat luas dapat timbul dari kisaran berbagai sumber, sebagai contohnya yang ada di dunia bisnis adalah (1) Risiko strategik adalah risiko terjadinya kegagalan mengantisipasi dan mengeksekusi inisiatif strategik perusahaan, (2) Risiko pasar adalah perubahan dalam nilai daktiva pasar perusahaan yang dapat diperdagangkan, (3) Risiko finansial adalah risiko kegagalan kendali keuangan, (4) Risiko operasional adalah risiko dari tindakan manusia, (5) Risiko komersial adalah risiko gangguan bisnis yang dapat timbul dari hilangnya personil penting, kegagalan pemasok, masalah hukum dan kepatuhan, (6) Risiko teknis adalah risiko kegagalan aset fisik, sebagai contoh adalah kegagalan peralatan, kerusakan infrastruktur, dan sebagainya; (7) Risiko reputasi adalah risiko yang dihubungkan dengan penurunan reputasi entitas perusahaan tersebut.

Berikut ini adalah beberapa definisi dari manajemen risiko, yaitu (1) Manajemen risiko adalah pendekatan yang kuat dan terkoordinasi untuk menilai dan merespon semua risiko yang mempengaruhi pencapaian tujuan strategik dan finansial organisasi. Ini meliputi risiko, baik dari sisi bawah maupun sisi atas (IIA - Institute of Internal Auditor); (2) Manajemen risiko adalah budaya proses dan struktur yang diarahkan menuju manajemen efektif atas potensi kesempatan dan pengaruh merugikan (Australian/New Zealand Standard); (3) Manajemen risiko adalah sebuah proses yang dipengaruhi oleh dewan perusahaan, maupun manajemen dan personil lain entitas tersebut, diterapkan dalam penetapan strategi dan berlaku di seluruh perusahaan, dirancang untuk mengenali peristiwa potensial yang dapat mempengaruhi entitas itu, dan mengelola risiko agar tetap ada dalam jangkauan risikonya sehingga dapat memberikan jaminan yang wajar mengenai pencapaian tujuan entitas (COSO - Committeeof Sponsoring Organization of the Treadway Commission).

Pengertian internal auditing yang tradisional terdiri dari konfirmasi bahwa pengendalian dsalam perusahaan sudah dilakukan dengan baik dan membuat recomendasi jika pengendalian tidak baik. Pihak yang membuat rekomendasi tersebut adalah internal auditor yang ditujukan kepada para manajer, dengan harapan para manajer tersebut dapat menerima. Dengan demikian, sistem tradisional ini menggambarkan bahwa internal audit bertanggung jawab terhadap pengendalian dan implikasi risiko dalam suatu manajemen. Akan tetapi, sesuai dengan Turnbull Guidance yang menekankan suatu realitas bahwa para manajer bertanggung jawab untuk pengembangan respon atas risiko-risiko dan memutuskan langkah-langkah yang harus diambil jika risiko-risiko tersebut tidak terkontrol dengan baik.

Perkembangan selanjutnya dalam internal audit adalah fungsi dan tugas internal audit bisa diklarifikasikan sebagai pemberi opini kepada manajemen tentang efektifitas dari manajemen dalam menghadapi risiko. Opini tersebut sekurang-kurangnya mencakup hal-hal tentang ketidakefektifan manajemen dalam mengontrol risiko yang ada. Dalam hal ini, internal audit masih dapat memberikan rekomendasi, namun sifatnya hanya sebatas konsultasi.

Untuk itu, dalam melakukan tugasnya, internal audit haruslah juga memperhitungkan faktorfaktor risiko yang ada. Pelaksanaan tugas Internal Audit dengan memperhatikan factor Risiko inilah yang lazim disebut Risk Based Internal Auditing (RBIA). Pelaksanaan RBIA ini melibatkan manajemen terlibat lebih jauh dalam penanganan risiko, yang di antaranya dapat dijelaskan sebagai berikut (1) Risiko-risiko yang tercakup dalam audit akan ada dalam semua bagian organisasi. Dengan demikian, manajer setiap departemen akan terlibat. Banyak risiko akan signifikan dalam organisasi dan diskusi mengenai cara menanggulanginya akan melibatkan senior manajer dan direktur; (2) RBIA menekankan tanggung jawab manajemen untuk mengatur risiko. Internal auditor terlibat dalam diskusi dengan para manajer mengenai risiko-risiko yang dihadapinya dan meminta respon para manajer atas risiko-risiko tersebut. Pelaksanaan hal ini mungkin diperlukan meeting permulaan dalam menghadapi risiko, termasuk juga penilaian risiko yang menentukan seberapa besar risiko yang ada; (3) Setelah dilakukan meeting pendahuluan, meeting selanjutnya diharapkan sudah mengurangi beban pemahaman 
terhadap risiko sehingga para manajer tinggal melaporkan tindakan apa yang harus dilakukan dalam kondisi risiko-risiko yang ada tidak dikendalikan dengan baik; (4) Kepala internal audit disyaratkan untuk memberikan profil perusahaan, yang tidak hanya meliputi bidang keuangan saja yang diharapkan agar para manajer lainnya dapat mengerti dan mampu memberikan masukan atas risiko yang sedang dihadapi perusahaan dari segala faktor; (5) RBIA mensyaratkan para manajer untuk berhadapan dengan risiko yang ada di departemennya. Jika perlu, para manajer tersebut harus membuat risiko-risiko yang ada di departemennya masing-masing. Dengan demikian, para manajer tersebut harus tahu bahwa tanggung jawab atas risiko perusahaan bukan menjadi tanggung jawab dari internal auditor, namun lebih luasnya adalah tanggung jawab dari masing-masing manajer.

\section{METODE PENELITIAN}

Objek penelitian adalah PT Indonesia Buffon Film (IBF) yang merupakan perusahaan patungan antara investor lokal dan investor asing, yaitu PT Du Pont International. Penelitian ini menerapkan metode studi kasus karena lebih memberi tekanan pada analisis terhadap kejadian yang ada di perusahaan. Bentuk studi kasus diplih dalam penelitian ini agar diperoleh pemahaman yang lebih mendalam tentang objek yang diteliti, yaitu perusahaan yang menerapkan Enterprise Risk Management yang digunakan sebagai bahan acuan Risk Based Internal Audit.

Metode studi kasus yang digunakan dalam penelitian ini didukung dengan beberapa pendekatan. Berdasarkan tujuan penelitian, maka penelitian ini menggunakan pendekatan deskriptif karena penelitian ini bertujuan untuk mengetahui kinerja perusahaan berdasarkan analisis Risk Based Internal Auditing. Pengumpulan data yang dilakukan di lapangan adalah melalui peninjauan secara langsung ke PT IBF yang menjadi objek penelitian. Beberapa cara yang dilakukan untuk memperoleh data antara lain (1) Wawancara. Data diperoleh dengan melakukan tanya jawab secara langsung dengan beberapa pimpinan serta setiap manajer dari setiap departemen. Teknik wawancara ini dilakukan untuk memberikan pemahaman yang lebih mendalam mengenai objek penelitian selain dari data-data fisik yang telah dikumpulkan; (2) Observasi. Teknik observasi ini dilakukan terhadap aktivitas operasional perusahaan yang berkaitan dengan permasalahan; (3) Kuesioner. Teknik penyebaran kuesioner kepada semua divisi yang ada di perusahaan ini yang kebetulan juga menjadi klien penulis selaku konsultan manajemen yang menyempurnakan fungsi internal control agar bisa bermanfaat secara optimal.

\section{HASIL DAN PEMBAHASAN}

\section{Hasil Temuan Utama Internal Control dan Risiko yang Harus Dikendalikan}

Seperti diuraikan sebelumnya, risiko utama dalam perusahaa ini adalah akumulasi rugi, dan diikuti risiko-risiko yang berkontribusi terhadap risiko utama. Untuk lebih memperjelas alur penerapan Enterprise Risk Management (ERM), yang didasarkan pada Risk Based Internal Audit (RBIA), manajemen mengacu kepada kerangka kerja ERM pada The Australian/New Zealand Standard in Risk Management (AZ/NZS 4360) yang membagi proses ERM dalam 7 langkah (Gambar 1). 


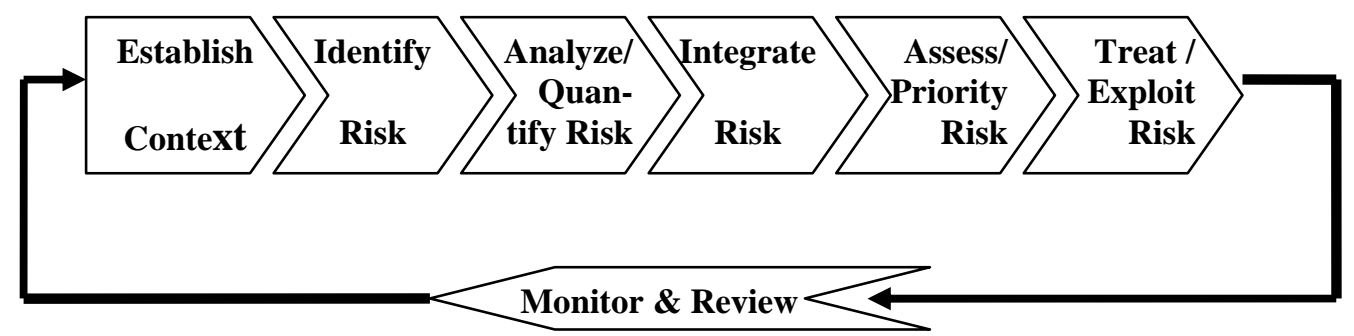

Gambar 1 Tujuh Langkah Enterprise Risk Management (ERM)

Departemen Business Audit dalam melaksanakan tugasnya berusaha mengikuti alur bagan dari proses mulai dari penentuan risiko sampai dengan proses pemantauan atau monitoring yang di-follow up dengan laporan kepada manajemen perusahaan. Berikut ini adalah hasil temuan dan identifikasi dari permasalahan yang ada di perusahaan, yang dikembangkan dan disosialisasikan oleh Departemen Business Audit untuk dikenali seluruh komponen perusahaan, kemudian ditindaklanjuti sesuai dengan tujuan perusahaan.

Langkah ini terdiri dari eksternal, internal, dan Risk Management Context. Context eksternal yang ada di PT IBF adalah bagaimana perusahaan ini berhubungan dengan pihak luar perusahaan. Termasuk dalam hal ini, yang sangat diperlukan adalah pemahaman mengenai SWOT analysis dari pihak eksternal terhadap PT IBF. Strength atau kekuatan PT IBF adalah mampu memasuki pasar internasional dalam memasarkan produknya, yang berupa Polyester Films. Pada tanggal 1 Januari 2000, manajemen perusahaan menandatangani Sales and Distribution Agreement dengan DuPont China Ltd. dan DuPont Taiwan Ltd., yang bertanggung jawab terhadap pemasaran di Hongkong dan Taiwan. Dengan agreement ini, pangsa pasar PT IBF di kedua negara tersebut menjadi terjamin. Agreement ini masih berlanjut sampai sekarang. Begitu juga pemasaran di Amerika Serikat dan Jepang. Related party perusahaan ini tersebar di seluruh dunia.

Dengan demikian, kekuatan perusahaan ini adalah di pangsa pasar internasionalnya. Weakness dari faktor eksternal hanyalah permasalahan penetapan harga. Meskipun berhubungan dengan related party, masing-masing party juga mempunyai target margin tersendiri sehingga harga jual yang rendah merupakan weakness dari faktor eksternal. Opportunity perusahaan ini dari fakctor eksternal adalah masih bisa dikembangkannya dialog untuk meningkatkan harga jual sehingga Buffon Film Group secara keseluruhan dapat meraih margin yang diinginkan dan masih tetap menguasai market international. Opportunity yang lain dari faktor eksternal adalah dari segi pembiayaan atau financing. Dengan melebarkan sayap ke seluruh dunia, maka bisa ditimbulkan yang kuat membantu yang lemah sesama group. Salah satu ancaman (threat) yang perlu diperhatikan adalah adanya produk dari China dan Eropa Timur yang mampu memproduksi produk sejenis dengan harga yang sangat kompetitif.

Context internal adalah bagaimana perusahaan dapat mengenali objektifnya dalam menangani permasalahan yang ada. Dalam hal ini, objektif internal utama yang harus dihadapi adalah bagaimana caranya menanggulangi atau mengurangi akumulasi kerugian agar perusahaan dapat survive di masa datang. Salah satu caranya adalah di masa yang akan datang manajemen haruslah mampu menghasilkan profit dan cash in dari operasional perusahaan semaksimal mungkin. Pengenalan permasalahan atau risiko yang dihadapi dalam menciptakan profit ini akan dibahas kemudian.

Contex Risk Management mulai dikembangkan semenjak hasil audit laporan keuangan tahun buku 2004 dan 2005. Dari hasil audit tersebut, terdapat catatan bahwa untuk ke depannya dengan uncertainty yang tinggi, maka dikhawatirkan perusahaan tidak dapat melanjutkan going concern-nya. Semenjak itu, semua lini manajemen berusaha melakukan pembenahan semaksimal mungkin agar 
operasional perusahaan tetap exist. Langkah ini meliputi pendokumentasian dan kejadian-kejadian yang mencerminkan ancaman material terhadap pencapaian objektif perusahaan atau representasi perusahaan dalam memenuhi competitive advantage. Identifikasi risiko ini merupakan risiko-risiko yang berkontribusi, baik langsung maupun tidak langsung terhadap risiko utama, yaitu akumulasi kerugian yang sangat besar. Risiko yang ada di PT IBF dapat diamati dan diidentifikasikan sebagai kompetensi manajemen, leadership, operasional mesin, oil price, simplifying/downsizing, internal control keuangan, kompetitor, dan ketersediaan modal/dana.

Pada tahap ini, perusahaan harus bisa menganalisis risiko yang ada untuk mendapatkan perhatian dan perlakuan yang baik (treatment), yakni di antaranya adalah (1) Kompetensi manajemen. Terbatasnya tingkat pengetahuan para anggota manajemen, khususnya di bidang financial dan accounting sehingga manajemen tidak dapat mengendalikan kapan harus bertindak efisien, khususnya terhadap permasalahan efisiensi costing; (2) Leadership. Rendahnya tingkat leadership dari manajemen perusahaan, dengan ditandainya setiap keputusan selalu menunggu persetujuan dari holding company di Jepang sehingga mengakibatkan lambatnya mengambil keputusan dalam pemecahan suatu permasalahan; (3) Operasional mesin, yakni kapasitas mesin yang tidak dioptimalkan. Dengan demikian, masih adanya idle kasity mesin yang tidak dimanfaatkan sehingga berakibat harga per unit produk tidak dalam ideal production cost; (4) Oil price, yakni harga bahan bakar minyak. Dengan adanya harga bahan baker minyak yang cukup tinggi, sangatlah membebankan perusahaan dalam bersaing. Sementara itu, kompetitor telah menggunakan alternative energy dengan menggunakan batu bara sebagai sumber energi bagi kepentingan utility-nya, yang secara hitungan ekonomis dan teknis jauh lebih murah dan mampu menghasilkan tenaga yang sebanding dengan sumber energi minyak; (5) Simplifying/downsizing. Adanya downsizing yang disyaratkan untuk mesimplify cost yang mengakibatkan perusahaan kehilangan personel yang kompeten di bidangnya sehingga banyak produk yang dikomplain para kustomer karena kurang memenuhi keinginan dari pelanggan; (6) Internal control. Lemahnya internal control yang dapat menciptakan peluang adanya fraud dan kulusi dalam berbagai siklus industri seperti siklus pendapatan, pembiayaan, produksi, dan pembayaran gaji; (7) Kompetitor. Berkembangnya para kompetitor dalam memasuki bisnis serupa yang mampu menghasilkan barang yang berkualitas hampir sama dengan produk perusahaan, namun dengan harga yang sangat rendah seperti produk dari China dan Taiwan; (8) Ketersediaan modal/dana. Mengingat akumulasi kerugian sudah melebihi 90\% setoran modal, maka ketersediaan dana yang deperlukan perusahaan sangatlah tergantung dari pendanaan dari luar yang berkonsekuensi pada kewajiban pembayaran bunga.

Dalam langkah ini, perusahaan berusaha untuk mengintegrasikan risiko-risiko yang ada untuk diunifikasi agar lebih fokus ke pemecahan permasalahan. Fokus utama adalah krisis menajemen yang sedang terjadi yang disebabkan oleh lemahnya leadership dalam perusahaan sehingga berakibat pada lemahnya internal control. Semuanya ini dapat mengarah pada kelemahan atau weakness yang berhubungan dengan fihak eksternal seperti kompetitor, dana ekstern, dan rentannya daya tahan perusahan dalam antisipasi faktor eksternal seperti dampak naiknya harga bahan bakar minyak.

Dalam tahap ini juga, manajemen diarahkan untuk memberikan prioritas utama yang berkontribusi terhadap risiko utama. Seperti telah dibahas dalam integrate risk, assess/prioritize risk merupakan tindak lanjut dari tahap sebelumnya. Dalam kasus ini, PT IBF harus memberikan prioritas utama pemecahan permasalahan, yang dapat digolongkan ke dalam faktor internal dan eksternal. Prioritas faktor internal lebih diutamakan kerena risiko ini bersifat dapat dikendalikan oleh manajemen, namun faktor eksternal amatlah tergantung dari perkembangan situasi global, baik lokal maupun internasional. Prioritas risiko tersebut dengan urutan (1) Internal, yakni leadership, kompetensi manajemen, internal control, simplifying/downsizing, operasional mesin; dan (2) Eksternal, yakni kompetitor, ketersediaan modal/dana, oil price. Dengan adanya pengidentifikasian risiko dan prioritas risiko yang ada di perusahaan, maka manajemen PT IBF bisa lebih mudah dalam meminimalisasikan risiko-risiko yang ada. 


\section{Pembahasan}

Sesuai dengan Assessment Risk di atas, perlu kiranya diminimalisasi kekurangan atau mengurangi timbulnya risiko yang lebih besar dengan urutannya sebagai berikut. Pertama, leadership. Para penentu keputusan di PT IBF mutlak dituntut untuk mengambil inisiatif kepemimpinan yang sigap dengan mempertimbangkan aspek teknis dan ekonomis dalam penentuan keputusan. Salah satu contohnya adalah dalam siklus industri. Manajemen harus cepat tanggap menentukan pilihan supplier mana yang dapat mensuplai bahan baku dengan harga murah dan tepat waktu. Kalau ada supplier yang bisa menyediakan itu semua dengan baik, meskipun supplier itu dari luar grup harus bisa diterima dengan cepat tanpa menunggu instruksi dari Jepang (Head Quarter). Selain itu, ketegasan pimpinan dalam menerapkan policy perusahaan dalam semua aspek juga dituntut untuk ditegakkan. Sebagai contoh adalah jangan segan-segan melakukan rolling pegawai, yang berfungsi untuk lebih memeratakan kemampuan dan transfer knowledge di antara pegawai. Begitu juga dalam kasus penjualan, pimpinan harus bisa menentukan sikap untuk bisa menjual produk kepada pihak luar group sepanjang harganya kompetitif.

Kedua, kompetensi manajemen. Manajemen dituntut harus bisa dengan cepat belajar terhadap perubahan baru dan juga dituntut untuk dapat membaca indikator-indikator ekonomi dan teknis. Sebagai contoh, manajemen harus dapat mempelajari indikator siklus produksi sehingga dapat menentukan sikap kapan harus meng-order bahan baku, kapan harus mengoptimalisasikan jam kerja mesin, dan juga overhead cost per satuan produk. Semua ini ada indikatornya seperti perputaran inventory, perputaran piutang, efisiensi aset dalam menghasilkan laba, aktivitas-aktivitas cash flow mulai dari aktivitas operasional, aktivitas investasi, dan aktivitas pendanaan, dan lain sebagainya. Semua jajaran manajemen harus peka teradap indicator-indikator tersebut. Jika tidak mengerti haruslah belajar dengan cepat, tidak boleh malas atau menunda untuk belajar. Mengejar kekurangan tersebut bisa didapat dari para ahli maupun belajar dari literatur-literatur yang ada.

Ketiga, internal control keuangan. Wibawa manajemen amatlah dituntut dalam mengimplementasikan internal control. Manajemen tidak boleh membuka peluang bagi karyawan untuk melakukan kecurangan (commit fraud). Salah satu contohnya adalah manajemen haruslah tanpa segan-segan memisahkan jabatan dalam struktur organisasi, juga menerapkan sistem rolling. Khususnya dalam sistem rolling, ada beberapa manfaat yang dapat diperoleh seperti semua pegawai akan mampu mengerjakan semua lini aktivitas perusahaan. Jadi, kalau ada karyawan yang berhalangan hadir dapat digantikan oleh yang lainnya. Rolling juga memberikan efek malu jika seseorang atau kelompok akan melakukan kecurangan, mereka akan kuatir kalau kecurangannya tersebut akan diketahui dengan cepat, dengan alasan pegawai yang dulu tidak pernah melakukan kegiatan seperti itu (kecurangan). Contoh yang kurang baik adalah manajer purchasing, dari pertama masuk jadi pegawai di PT IBF sampai pension, tetap di bagian purchasing. Hal ini amatlah membuka peluang bagi orang tersebut untuk berkonspirasi dengan supplier.

Keempat, simplifying/downsizing. Perlakuan simplifying yang bertujuan untuk efisiensi tidak boleh dilakukan dengan asal memangkas jumlah karyawan, tapi harus melihat mana karyawan yang berpotensi dengan yang tidak sebab karyawan yang berpotensi merupakan aset perusahaan yang sulit mendapatkan gantinya dengan cepat. Kelima, operasional mesin. Operasional mesin harus juga diperhatikan, jangan sampai mesin yang berkapasitas 11.000 ton mengolah biji plastik per tahun, tapi hanya digunakan untuk mengolah 8.000 ton saja. Dengan demikian, energi yang telah terbuang selama setahun sebesar 3.000 ton. Dengan demikian, harga pokok per satuan produk menjadi lebih tinggi. Juga faktor yield produk harus diperhatikan. Tidak boleh terjadi waste produk terlalu besar, yang hanya dapat dijual dengan harga murah. Selama ini keadaan yang ada adalah waste produk masih tinggi, namun sikap manajemen kurang tegas terhadap hal ini. Disinyalir bagian produksi berkorporasi dengan para penadah produk waste di sekitar pabrik. 
Keenam, kompetitor. Risiko kompetitor susah untuk diatasi. Salah satu cara yang bisa diusulkan adalah membentuk suatu asosiasi sesama industri sejenis sehingga harga jual dan perolehan bahan baku bisa dimusyawarahkan bersama. Apabila kompetitor di luar negeri, maka bisa dilakukan dengan mengadakan agreement penjualan bersama. Menghadapi risiko kompetitor, sesuatu yang bisa dikendalikan oleh manajemen adalah menciptakan efisiensi operasional perusahaan seoptimal mungkin. Ketujuh, ketersediaan modal/dana. Akumulasi kerugian yang melanda bertahun-tahun mulai tahun 1996, semenjak berdirinya PT IBF amatlah sulit bagi manajemen untuk tidak berhubungan dengan pendanaan luar. Harapan bisa mencukupi dana dari kemampuan sendiri melalui aktivitas operasi dari cash flow sangatlah sulit. Untuk itu, hubungan dengan pendana luar harus baik. Namun, risiko yang ditimbulkan atas pendanaan luar juga harus diperhitungkan dengan baik seperti faktor bunga. Untuk mengurangi ketergantungan kepada pihak luar, manajemen haruslah menciptakan cash in dengan sebanyak-banyaknya dari aktivitas operasional untuk masa mendatang.

Kedelapan, oil price. Risiko melonjaknya harga minyak dunia merupakan di luar jangkauan dari kemampuan manajemen. Salah satu cara untuk mengatasi hal itu adalah diciptakannya sumber energy, semisal dari batu bara atau bio diesel. Dengan adanya energi alternatif ini, perusahaan tidak akan selalu khawatir dengan tidak stabilnya harga minyak dunia. Namun, energi alternatif ini juga harus perlu mendpat perhatian pengadaannya sebab energi alternatif lain akan memerlukan investasi tambahan yang harus diintegrasikan dengan konstruksi mesin-mesin yanga ada.

Monitoring dan review amatlah diperlukan dalam penerapan Risk Based Audit berdasarkan pada manfaat pengenalan diri sendiri melalui ERM. Proses monitoring ini bertujuan apakah risikorisiko yang sudah ditentukan dan upaya cara untuk meminimalisasikannya telah efektif dan efisien atau tidak. Dengan adanya identifikasi risiko tersebut, apakah profit bisa dicapai sesuai dengan yang sudah di-budget kan apa belum. Kalau belum, maka haruslah lebih serius lagi untuk melaksanakan treatment terhadap risiko tersebut. Proses monitoring dan review ini, dapat dilaksanakan dalam sistem quarter, semester, dan tahunan. Hasil monitoring ini harus dirapatkan antar manajemen sehingga integrasi solusi permasalahan dapat dilaksanakan secara komprehensif di lingkungan perusahaan.

\section{SIMPULAN}

Pada bagian akhir dari penulisan ini, penulis berusaha menyimpulkan apa yang ada dalam kenyataan operasional perusahaan PT IBF. Dalam operasionalnya, PT IBF berusaha mengatur pengendalian internal secara efisien dan mantap. Untuk itu diperlukan suatu alat bantu atau tools dalam pelaksanaan hal tersebut. PT IBF dalam usahanya melaksanakan internal control berusaha mengadopsi sistem pengenalan dan pengendalian risiko berdasarkan The Australian/New Zealand Standard in Risk Management (AZ/NZS 4360), yaitu suatu konsep dalam pengenalan dan me-manage risiko yang ada, yang umumnya disebut Enterprise Risk Management (ERM).

Pengenalan atas ERM ini saja tidaklah cukup kalau hanya dilakukan atau digunakan sebagai teori semata. tanpa ada pengimplementasiannya di dunia nyata operasional perusahaan. Untuk itu, sebagai kegiatan monitoring, agar supaya proses pengendalian internal control berjalan dengan baik, manajemen perusahaan mendirikan suatu departemen khusus, yaitu Department Business Audit yang dalam tugasnya mengemban memonitor internal control perusahaan, dengan menjunjung tinggi mental independensi demi tercapainya tujuan perusahaan.

Pelaksanaan The Australian/New Zealand Standard in Risk Management (AZ/NZS 4360) sudahlah kompleks, yang mana di dalam teori ini telah terjadi adanya penggabungan tujuan yang juga membantu tujuan utama dari Risk Based Internal Auditing. Dilihat dari satu per satu step pada standar ini, yang dimulai dari establish context, identify risk, analysze/quantity risk, integrate risk, 
assess/priority risk, treat/ exploit risk, monitoring, dan review telah menunjukkan praktik dalam implementasi Risk Based Inernal Auditing, di mana perlu analisis proses mulai pengenalan masalah yang ada, identifikasi tipe-tipe risiko yang ada, perhitungan risiko dan audit risiko, proses pengendalian risiko serta pentingnya pelaporan risiko.

Secara keseluruhan, PT IBF telah berhasil dengan baik mengenali kemungkinan risiko yang ada di dalam operasinal usahanya. Namun, masih ada juga celah-celah kelemahan yang ada yang harus dianalisis dan di-follow up lebih lanjut oleh manajemen. Celah-celah kelemahan yang harus segera dikendalikan tersebut adalah sebagai berikut. Pertama, independensi dari Department Business Audit. Menurut pengamatan penulis, independensi business audit masih belum maksimal. Hal ini yang menjadikan bahan pertanyaan penulis, apa penyebab terjadinya hal tersebut. Apakah solider antar teman yang begitu kuat sehingga business audit merasa enggan untuk melaporkan keadaan yang ada di lapangan, atau apakah ada rasa tekanan dan ancaman. Hal ini mengingat bahwa business audit melalui wawancara dengan penulis telah memaparkan risiko-risiko yang ada dan bagaimana cara mengatasinya. Namun, masih banyaknya kekurangan yang ditemui penulis seperti lemahnya internal control pengeluaran keuangan. Untuk itu, perlu adanya training dan pemahaman pentingnya kerjasama, tapi dalam hal yang positif untuk memacu kinerja perusahaan. Peran dari pimpinan puncak perusahaan sangatlah diperlukan dalam hal ini seperti peran dewan direksi maupun manajer personalia.

Kedua, pelaporan. Seperti yang diutarakan penulis sebelumnya bahwa pelaporan adalah memegang penting dari pelaksanaan RBIA. Namun, yang penulis temui di perusahaan ini adalah pelaporan sifatnya hanya penyajian data semata, bukannya bersifat kesimpulan yang didukung dengan kenyataan data yang ada. Dengan demikian, masih seringkali dijumpainya kenyataan yang ditemui penulis bahwa kejadian dan risiko yang ada dibiarkan begitu saja, tanpa ada tindak lanjut untuk mengatasinya. Dalam hal ini, penulis menggarisbawahi bahwa lemahnya pelaporan dapat menyesatkan informasi yang masuk ke penentu keputusan sehingga permasalahan yang seharusnya ditindaklanjuti dengan baik, maka tidak mendapatkan penanganan atau tidak ditindaklanjuti sama sekali. Untuk itu, perlu ditingkatkan kualitas pelaporan dari hasil temuan, analisis, dan saran-saran perbaikan yang harus dilakukan.

Ketiga, human resources business audit. Business audit memegang peranan penting dalam pelaksanaan ERM dan RBIA. Untuk itu, diperlukan personalia yang handal dan tajam dalam menganalisis keseluruhan operasional perusahaan. Namun, yang penulis dapati bahwa personal di Business Audit Department belumlah mempunyai kualitas yang diingingkan, atau dalam artian kemampuan personel di business audit masih setaraf dengan kemampuan klerikal yang hanya mempunyai kemampuan menyajikan data mentah, tanpa ada analisis yang baik dan benar. Untuk itu, penulis perlu menyarankan supaya personel dalam business audit perlu mendapatkan training yang lebih memadai, terutama dalam menganalisis risiko-risiko perusahaan dan bagaimana cara melaporkannya dengan baik kepada pihak-pihaak penentu keputusan di PT IBF.

Demikianlah akhir dari penelitian ini, yang bertemakan "bagaimana implementasi pelaksanaan RBIA”. Pelaksanaan RBIA tentunya juga didasari atau ditunjang oleh hal-hal lain seperti pengenalan dan cara manajemen risiko yang baik (ERM), praktik internal control dan internal audit yang baik, yang telah memenuhi standar yang diakui atau dianggap wajar oleh pengguna informasi perusahaan atau para stakeholder yang mempunyai kepentingan atas operasional perusahaan. 


\section{DAFTAR PUSTAKA}

Barton, T.L., Shenkir, W.G., and Walker, P.L.. (2002). Making enterprise risk management pay off: How leading companies implement risk management, FEI research foundation \& Prentice Hall FT.

Bell, C., Blackburn, S., and Chambers, A. (2004). Internal audit service, CCH.

Belmont, D.P. (2004). Adjusted performance measurement, CFA. Wiley Finance.

Bowden, A.R., Lane, M.R., and Martin, J.H. (2001). Triple bottom line risk management: Enhancing profit, environmental performance, and community benefits, USA: John Wiley \& Sons, Inc.

Dallas, G. (2004). Governance and risk: An analytical handbook for investor, managers, directors, stakeholders, USA: MC Graw-Hill.

Dembo, R.S., and Freeman, A. (1998). The rules of risk: A guide for investors, USA: John Wilwy \& Sons, Inc.

Lam, J. (2003). Enterprise risk management: From incentives to controls, Wiley Finance.

McCarthy, M.P., and Flynn, T.P. (2003). Risk: From the CEO and board perspective, USA: McGraw Hill.

Pickford, J. (2001). Mastering risk: Concepts, volume 1, Prentice Hall-Financial Times.

Shimell, P. (2002). The universe of risk: How top business leaders control risk and achieve success, Prentice Hall-Financial Times. 